\title{
The Relationship Of Environmental Knowledge And Green Purchase Intention
}

\author{
Oda I. B. Hariyanto, Doni Purnama Alamsyah
}

\begin{abstract}
Nowadays, customer's knowledge of the environment is very important, remember that its impact on customer behavior for product consumed. So the study of customer behavior for an environmentally friendly product which is environmental knowledge and green purchase intention become research focus through the correlation study among variable. This study focuses on the retail customer which are 100 customers, where it had experience before about environmental friendly product in Bandung City, Indonesia. Through experimental study is conducted hypothesis test with simple regression analysis, with data obtained from questionnaire distribution. The research finding is stated that there is a correlation from the improvement of green purchase intention as the impact of environmental knowledge of customer for the environmentally friendly product. It needs to be known that environmental knowledge still focuses on the impact of product production on the environment, while knowledge of product characteristic has not become important attention. It explains that environmental knowledge needs become attention if it is related to the customer purchasing behavior of an environmentally friendly product.
\end{abstract}

Index Terms: Environmental Knowledge, Green Purchase Intention, Environmental Friendly Products

\section{INTRODUCTION}

Customer purchasing behavior becomes attention to all of the marketers nowadays (1), especially for environmentally friendly products (2). Remember there is changing of customer consumption pattern in some decades to face the environmental damaging issue with consumption pattern on environmentally friendly products, it is commonly called green consumerism (3). This behavior grows well in developing countries; it is supported not only the higher of purchasing power but also because of environmental knowledge that is better (4). So the customer's education for goods or services needed becomes an important part of the company to be noticed today. It seems from information in advertising which is educative to product offered (5). This case is in order to encourage customer's knowledge and it can stimulate green purchase intention (6).

As having known that the development of environmental products like organic products has been better in developing countries (7). However, it needs to be reviewed in developing country like Indonesia remember it is known one of the issues that there is still low of organic product offering as one of the environmentally friendly products at Supermarket (8). It explains indirectly to customer acceptance of environmentally friendly products which has

Revised Manuscript Received on April 19, 2019.

Oda I. B. Hariyanto, Departement of Hospitality, Universitas Internasional Batam, Batam, Indonesia.

Doni Purnama Alamsyah, Departement of Magister Management, Universitas BSI, Bandung, Indonesia not developed well. An environmentally friendly product like organic products is developed by industry in Indonesia through a more complicated process than conventional products (6), it becomes one of the reasons why organic products are more expensive. However, organic product is given a special label which is eco-label as a differentiator of a common product with healthier information to be consumed and it becomes a premium product (9). Besides that, organic products sold at Supermarket seems to be provided by the information of additional advertisement about the nutritional content of the product which is outperformed than the conventional product (10).

Reviewing from the phenomenon of customer purchase behavior for environmentally friendly products, so research study focuses on factor analysis of environmental knowledge and its correlation to green purchase intention for environmentally friendly products. This study is important in the relation of supporting customer behavior which is proto environment and it improves the development of environmentally friendly products in Indonesia. Remember that Indonesia is a country with the development of environmentally friendly products is still in the introduction stage.

\section{LITERATURE REVIEW}

\section{A. Environmental Knowledge}

Environmental knowledge is a general knowledge about fact, concept, and the correlation between the natural environment with ecosystem surrounding (11). Furthermore, it is explained that environmental knowledge relates to customer's knowledge level of the environment (9). Those environmental knowledge relate to understanding and attention about the natural environment, and it encourages individual responsibility who is more powerful to protect the environment. Environmental knowledge can be improved by the customer's understanding of green awareness (9), it means that a customer's knowledge will improve if they are aware of their needs. In general, environmental knowledge relates to customer's knowledge for the impact of a greenhouse, the impact of pesticide and pollution use, the impact of forest logging and the impact of environmental habitat (9). But relating to customer behavior in product research, environmental knowledge can be assessed practically from several sides such as no animal testing in product making, product with natural ingredient, product impacts to sustainable forest; it is known as organic product,

Published By:

Blue Eyes Intelligence Engineering 
it has an impact on ozone-friendly aerosols, biodegradability, unleaded petrol, and minimum packaging materials (12).

\section{B. Green Purchase Intention}

Green consumerism has close relation with green purchase intention (7), in which green purchase intention has customer behavior related to customer intention for environmentally friendly products assessed (13). Those intentions develop well for the encouragement of environmental knowledge. Green purchase intention is simply stated as customer's prediction for environmentally friendly products (14). The intention is a basic of customer behavior about the existence motivation does an action (14). If it is supported by the sufficient information, so those intentions develop well and it leads to positive value from information that obtained as customer purchase behavior (15). Basic of the customer' s motivation for environmentally friendly products can be reviewed from the information about environmentally friendly products like eco-label or other attributes support (9). The development of an environmentally friendly product like organic products in Indonesia is still in the introduction stage (16), so there is limited information about organic products. It does not encourage surely to customer behavior in green purchase intention. Relating to green purchase intention, it can be assessed from some indicators which are having consideration to buy, priority to buy, feeling to buy and recommendation to buy (13).

\section{METHODS AND HYPOTHESIS}

The study focused on the correlation between variable environmental knowledge and green purchase intention. Data and information were obtained through a questionnaire which spread to 100 respondents; the selected respondent had known the knowledge of organic products at Supermarket in West Java. This experimental study was conducted factor analysis test and hypothesis test to know the significance level of correlation among variable.

\section{RESULTS AND DISCUSSIONS}

\section{A. Profile Respondent}

This study is conducted in 2018 with a total of 100 customers who knows about environmentally friendly products like organic product at a Supermarket. The questionnaire is distributed directly to the customer at the Supermarket in Bandung City as the capital city of West Java. From questionnaire data processed, it has known that many of them are female $(51 \%)$ then it is followed by a male $(49 \%)$. The average respondent's age is dominated by young age which is about 20-30 years old with the percentage is $78 \%$ with the average status is married $(65 \%)$. From the number of a family member, the average is $2-5$ people with a percentage of $53 \%$ and the last educated is senior high school graduated with a percentage of $52 \%$. It is reviewed from monthly income with the average is 2-6 million and the percentage of $59 \%$. The next study is conducted data processing based on the questionnaire using SPSS to coefficient value test and hypothesis test (Table 1, Table 2).

\section{B. Coefficients Test}

Based on Table 1, the equation obtained through regression coefficient test explained that environmental knowledge has positive regression coefficient which is about 0.221 , it means that the increase on the variable of knowledge of environment will be accompanied by the increasing on green purchase intention. From T-test result, knowledge about the environment influenced significantly towards the purchase intention of environmentally friendly products. It depends on test result $3.007>1.660\left(\mathrm{t}_{\text {-count }}>\mathrm{t}\right.$. table $)$, and the significance value $(P$ value $)<0,05 \rightarrow 0,00<$ 0,05 .

Coefficient of Determination $\left(\mathrm{R}^{2}\right)$ aims to measure how far the model ability in explaining the variation of the dependent variable. Based on Table 2, determination test result $\mathrm{R}^{2}$ explains that $\mathrm{R}^{2}=0,684$, it means that environmental knowledge influences the purchase intention of environmentally friendly products that are about $68,4 \%$.

\begin{tabular}{|c|c|c|c|c|c|c|}
\hline \multicolumn{7}{|c|}{ Table 1. Coefficient Valae } \\
\hline & \multirow[t]{2}{*}{ Vaniable } & \multicolumn{2}{|c|}{$\begin{array}{l}\text { Unstandardizad } \\
\text { Coefficiants }\end{array}$} & \multirow{2}{*}{\begin{tabular}{|c|}
$\begin{array}{c}\text { Standardined } \\
\text { Coefficients }\end{array}$ \\
Beta \\
\end{tabular}} & \multirow[t]{2}{*}{$t$} & \multirow[t]{2}{*}{ Sig } \\
\hline & & B & Std. Error & & & \\
\hline \multirow{2}{*}{1} & (Constart) & 24764 & 2.172 & \multirow{2}{*}{291} & 11.403 & .000 \\
\hline & Environmental Knowledge & 221 & .074 & & 3.007 & .000 \\
\hline
\end{tabular}

a. Dependert Vanable: Grean Purchase Intention

Table 2. Coefficient Determination Value

\begin{tabular}{|c|c|c|c|}
\hline Model & R & R Square & Adjusted R Square \\
\hline 1 & $.691^{\mathrm{a}}$ & .684 & .675 \\
\hline
\end{tabular}

a. Predictors: (Constant), Environmental Knowledge

b. Dependent Variable, Green Purchase Intention

\section{The Influence of Environmental Knowledge on Green} Purchase Intention

Reviewing from research result has been known that there is a correlation between environmental knowledge and green purchase intention (Table 1). It explains that the higher of environmental knowledge of the customer, so the better in supporting to green purchase intention of the customer. The number of influence of environmental knowledge is about $68 \%$ in the improvement of green purchase intention (Table 2). Environmental knowledge of customer is the customer's point of view for the science of environmentally friendly products (3), this opinion is built from several indicators which are No animal testing in product making, product with natural ingredient, product impacted to sustainable forest; it is known as organic product, it has an impact on ozone-friendly aerosols, biodegradability, unleaded petrol, and minimum packaging materials (12). All of the measurement indicators are actually have the most dominant size that forms environmental knowledge of customer which is biodegradability, unleaded petrol, and minimizing packaging materials. It means that it needs to be understood by the marketer in creating environmentally friendly 
products needed to see from the ability side of product related to biodegradability, unleaded petrol, and minimizing packaging materials. For marketers, by understanding the level of importance based on the measurement in environmental knowledge, marketing has the opportunity to improve customer's understanding of environmental knowledge that impacts customer purchasing behavior. This study explains that customer purchasing behavior for the environmentally friendly product which is green purchase intention can be improved by a good understanding of environmentally friendly products in environmental knowledge. It is in line with previous studies (6), that customer purchasing behavior is determined by the factor of environmental knowledge. So environmental knowledge can be a basic for marketer towards environmentally friendly products in controlling green customer behavior.

\section{CONCLUSIONS}

Environmental friendly products become study focus in this research with the study area on customer behavior for environmental knowledge and green purchase intention. Customer who becomes study focus is the customer who has knowledge of environmentally friendly products like organic product at a Supermarket. It has been known that customer behavior which is green purchase intention can be controlled by customer's understanding for information of no animal testing on the product, organic vegetables, unleaded petrol, and information of minimum packaging materials on environmental knowledge. So it can be concluded that environmental knowledge is a basic of customer's behavior for product attributes like eco-label; in fact, it differs the characteristic of environmentally friendly products. It is obviously research limitation and it is suggested further in the research study of environmentally friendly products with customer behavior

\section{REFERENCES}

1. Walsh G, Bartikowski B. Exploring corporate ability and social responsibility associations as antecedents of customer satisfaction cross-culturally. J Bus Res [Internet]. 2013;66(8):989-95. Available from: http://dx.doi.org/10.1016/j.jbusres.2011.12.022

2. Syarifuddin D, Alamsyah DP. Green Perceived Value for Environmentally Friendly Products: Green Awareness Improvement. J Ekon Pembang. 2017;18(2):245-55.

3. Kautish P. The Determinants of Consumer Willingness to Search for Environmental-Friendly Products : A Survey. Int J Manag. 2012;29(2):696-712.

4. Suki NM. Green awareness effects on consumers' purchasing decision: Some insights from Malaysia. Int J Asia-Pacific Stud. 2013;9(2):49-63.

5. Angelovska J, Sotiroska SB, Angelovska N. The Impact of Cognitive Learning on Consumer Behaviour. J Int Environ Appl Sci. 2012;7(2):406-17.

6. Alamsyah DP, Trijumansyah A, Hariyanto OIB. Mediating of Store Image on Customer Trust for Organic Vegetables. MIMBAR, J Sos dan Pembang. 2017;33(1).

7. Paço AMF, Raposo MLB. Green Consumer Market Segmentation: Empirical Findings From Portugal. Int J Consum Stud. 2010;34(1996):429-36.

8. Alamsyah DP, Syarifuddin D. Store Image: Mediator of Social Responsibility and Customer Perceived Value to Customer Trust for Organic Products. IOP Conf Ser Mater Sci Eng. 2018;288.
9. Rashid NRNA. Awareness of Eco-label in Malaysia's Green Marketing Initiative. Int $J$ Bus Manag. 2009;4(8):P132.

10. Rahim MHA, Zukni RZJA, Ahmad F, Lyndon N. Green advertising and environmentally responsible consumer behavior: The level of awareness and perception of Malaysian youth. Asian Soc Sci. 2012;8(5):46-54.

11. Safari A, Salehzadeh R, Panahi R, Abolghasemian S. Multiple pathways linking environmental knowledge and awareness to employees' green behavior. Corp Gov Int J Bus Soc. 2018;CG-08-2016-0168.

12. Rashid NRNA, Khalid SA, Rahman NIA. Environmental Corporate Social Responsibility (ECSR): Exploring its Influence on Customer Loyalty. Procedia Econ Financ. 2015;31(15):705-13.

13. Chen Y, Chang C. Enhance Green Purchase Intentions. The Roles of Green Perceived Value, Green Perceived Risk, and Green Trust. Manag Decis. 2012;50(3):502-20.

14. Othman C, Rahman MS. Investigation of the Relationship of Brand Personality, Subjective Norm and Perceived Control on Consumers' Purchase Intention of Organic Fast Food. Mod Appl Sci. 2014;8(3):92-106.

15. Wu S, Chen Y. The Impact of Green Marketing and Perceived Innovation on Purchase Intention for Green Products. Int J Mark Stud. 2014;6(5):81-101.

16. Mayrowani H. Pengembangan Pertanian Organik di Indonesia. Forum Penelit Agro Ekon. 2012;30(2):91108 .

\section{AUTHORS PROFILE}

Oda I. B. Hariyanto, lecture, and researcher from Universitas Internasional Batam, Indonesia. Now, she as Head of Tourism Departement. Oda was graduated as Doctor for Culture Heritage from Universitas Padjadjaran in 2015. Have certificate as Hotel Manager (CHM) in 2018. She interests in research for Culture, Tourism and

Food area.

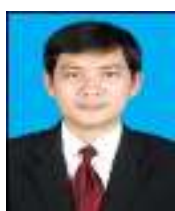

Doni Purnama Alamsyah, lecturer and researcher from Universitas BSI in Indonesia. Have a Doctoral Degree in Marketing Management since 2015 from Universitas Padjadjaran, Indonesia. Now, He focuses and also interests in research with Green Customer Behavior area 